\title{
India backing wrong technologies, report says
}

New Delhi. India needs to reverse its research spending priorities by putting more emphasis on agriculture and biotechnology, and less on defence, nuclear power and space, according to a government report. The report says the current research priorities are out of touch with the government's economic and social goals.

The report, Technology Priorities for India, has been released by the Technology Information Forecasting and Assessment Council (TIFAC), a unit of the Department of Science and Technology. It warns that "the balance is tilted so much in favour of military and strategic strength at the expense of economic development that it could imperil national integrity".

Defence, nuclear power and space have eaten up more than half of India's research spending for decades, while health, agricultural and industrial research have received less attention. TIFAC says India's pattern of technology spending is "remarkably similar to that of the Soviet Union just before it broke up".

The report acknowledges that some strategic industries are needed to protect national security. But it argues that spending has ignored the "link between economic development and India's survival as a nation state". And the proportion of resources spent on developing "strategic" technologies is disproportionate to their impact on the economy.

The combined output of the defence, nuclear power and space sectors is only US $\$ 2.5$ billion, estimates the report, whereas agriculture accounts for $\$ 71$ billion of gross domestic product (GDP) and other industries account for $\$ 31$ billion. India's

\section{Nuke ship reincarnated}

Tokyo. The controversial nuclear-powered ship Mutsu was relaunched last week in Tokyo Bay after a $¥ 20$ billion (US\$200 million) refit as one of the world's largest oceanographic and meteorological research vessels. The 8,600-tonne vessel now belongs to the Japan Marine Science and Technology Centre. It has been stripped of its nuclear reactor and given a diesel-electric hybrid propulsion system. The vessel, renamed Mirai ('future'), will have a crew of 80 , including 28 researchers.

Japan has invested more than $¥ 100$ billion and nearly 30 years of effort in the vessel. It was launched in 1968 but protests about potential radioactive pollution delayed its maiden voyage by six years.

When it finally set sail its reactor sprang a leak and years of controversy followed as the unwanted vessel was towed from port to port. The controversy brought an end to Japanese ambitions to develop nuclear-powered ships.

R. N. textile, leather and chemicals industries generate much more money than defence, but spending on research in those areas is onefifteenth of that spent on defence.

The report points out that India spent $\$ 300$ million on nuclear power last year but this generated only 3 per cent of the electricity supply. Thermal power technologies received just $\$ 20$ million, although almost three-quarters of India's electricity is produced from coal.

TIFAC urges the government to redefine technology spending priorities in terms of their potential contribution to GDP. According to the study, that would put agricultural research at the top of the list, followed by industrial and health-related research and development, and would leave defence sixth, nuclear power seventh and space ninth. Biotechnology would also be a priority for spending.

In support of this approach, the report argues that, even if India should succeed in developing new armaments, these would be "extremely unlikely" to find export markets. But "even incremental improvements in

\author{
IMAGE \\ UNAVAILABLE \\ FOR COPYRIGHT \\ REASONS
}

Kalpakham nuclear power station: what price nuclear know-how?

agricultural technology" would make India a major exporter of food, with a large impact on the nation's wealth.

The TIFAC report appears to have cut little ice with the government, however. Yoginder Alagh, the newly appointed science minister, says spending on research in "strategic areas" will need to remain high for reasons of national security. "These are areas in which we cannot get help from any other country," he says. K. S. Jayaraman

\section{Ebola bar creates monkey shortage}

Tokyo. Japanese scientists say that the rising cost of monkeys and a shortage of supply is hindering research on HIV vaccines and vectors for gene therapy. They blame the problem on a decision made in 1990 by Japan's two major inter-national carriers -

\section{IMAGE UNAVAILABLE FOR COPYRIGHT REASONS}

A dying breed: 'research' monkeys are in short supply in Japan.

Japan Airlines and All Nippon Airways to stop importing certain species of monkeys to guard against the entry of the Ebola virus.

The decision to stop importing rhesus, cynomolgus and African green monkeys from Africa and South-East Asia for biomedical research was made following international concern about the spread of the virus. The airlines consulted the health ministry but it issued no official restrictions.

Korean Airlines subsequently introduced a similar ban, leaving just one foreign airline in the business of shipping monkeys to Japan. The restricted supply has caused the price of research monkeys to rocket. Five years ago a cynomolgus monkey cost $¥ 150,000$ (US\$1,500) but now it is almost three times that much.

Biomedical researchers say that wild monkeys are more likely to carry viruses and parasites than monkeys bred in captivity for research purposes. The researchers want the government to launch a review of the industry, which they hope will lead to improved supply and better safety standards.

The health ministry acknowledges the potential risks of monkeys imported as pets. One pet-shop owner caught dysentery after importing a monkey, which later died of unknown causes. The ministry may set up a committee to assess the danger and to study biomedical research needs, says an official.

Pharmaceutical companies say that the shortage and high cost of monkeys is creating a bottleneck in the development of gene-therapy vectors and AIDS vaccines, according to Mitsuru Miyata, editor of Nikkei Biotechnology, an industry newsletter.

Japan's only clinical trial of a gene therapy last year relied on a US retroviral vector, and on data from the US Food and Drug Administration on its safety and efficacy.

Concern that Japan is falling behind in the race to develop and patent vectors led to the creation last year of a governmentbacked research and development company, DNAVEC. As well as developing vectors, the company plans to produce methods for testing their safety and efficacy. This cannot be done without a steady supply of monkeys.

Richard Nathan 